\title{
Discipline Strategies: Influence on Gender and Academic Level of Students: A Case of Rachuonyo North Sub-County, Homabay County, Kenya
}

\author{
Winnie Awuor Odhiambo \\ Esther Kiaritha \\ Moi University, Kenya \\ John M. Momanyi \\ Bomet College Campus, Kenya
}

doi: 10.19044/ejes.v4no3a6 URL:http://dx.doi.org/10.19044/ejes.v4no3a6

\begin{abstract}
This paper purposed to establish if there was a significant influence of discipline strategies on student academic performance based on the gender and academic level of students in Homabay County, Kenya. Over the years, students in Rachuonyo North Sub County have continued to perform poorly in Kenya Certificate of Secondary Education (K.C.S.E). The objective of this study is to determine the influence of discipline strategies on academic performance by gender and academic level. The research design used was causal comparative. The researcher used simple random sampling to select 23 schools. Purposive sampling was used to identify students at different academic levels who had received any of the three discipline strategies that is suspension, manual labour, and sending students home to call their parent. The quantitative data was analyzed using paired sample t-test and repeated measures ANOVA at .05 level of significance. The study findings indicated that girls performed poorly after discipline strategies had been used on them. However, there was no significant difference in the academic performance of boys after the discipline strategies. It emerged that these discipline strategies influenced students' academic performance differently depending on the academic level of the student with the form two and four students registering a decline and the form three students showing a slight improvement. The study recommends discipline strategies other than the three used in the study for girls. Further research is required to determine the influence of these discipline strategies in other counties.
\end{abstract}

Keywords: Discipline Strategies, Academic performance, gender, Academic level, High school students, Kenya. 


\section{Introduction}

School discipline refers to all the strategies which are used to regulate, coordinate, and organize students and their activities in the school as well as put in place the provision and procedures necessary to establish and maintain a conducive environment in which teaching and learning can take place (Thornberg, 2008). In Kenya education system, the advancement of students is solely based on student academic performance in national examinations (Nyagaka \& Odongo, 2013). For this reason, the national examinations were used above all to select those suitable to proceed to the next stage of education. Due to this emphasis on national examination, every single Kenyan in the education setup strives to attain a good grade in order to proceed to the next level. Also, any case of poor performance is taken seriously. While poor performance is applicable to most counties in the country, other counties have a record of perennial mass failures in national examinations. This is especially so in Homabay County where students have continued to perform poorly in KCSE (Nyagaka \& Odongo, 2013; Ogwen, Kathuri \& Obara, 2014). Due to this poor performance, most stakeholders in the district including teachers, parents, and education officers are looking for answers to explain this phenomenon. Although there are several factors which have been documented to have influenced the academic performance of students in Rachuonyo North Sub County (Ogweno, Kathuri \& Obara, 2014), discipline strategies as a factor has not been looked into. It is therefore important to have an in depth assessment of the influence of discipline strategies on academic performance of students in terms of gender and academic or class level of students. The discipline strategies included in this study are: suspension, manual labour, and sending students home to call their parents.

\section{PURPOSE AND OBJECTIVES OF THE STUDY}

The purpose of this study is to determine the influence of discipline strategies on academic performance of girls and boys in Homabay County. In order to attain this purpose, the study was guided by the following objectives:

1. To determine the influence of discipline strategies on academic performance by gender.

2. To determine the influence of discipline strategies on academic performance by academic level.

\section{MATERIALS AND METHODS}

The study was conducted in Rachuonyo North Sub County in Homabay County. The study employed causal comparative research design whose main purpose was to explore the interlink between variables (Mugenda $\&$ Mugenda, 1999). The population of the study comprised of 23 schools in 
Rachuonyo North Sub County, Homabay County. The accessible population were form 2, 3, and 4 students. The researcher used document analysis for the students. This involves analysis of documentary materials that are in print form (Kothari \& Gaurav, 2014).

Simple random sampling was used to select 23 schools out of the 43 schools in the county. Purposive sampling was thereafter used to identify the form 2, 3, and 4 students who had received any of these discipline strategies with the help of the class teachers. The researcher went through the documents containing the students' results in order to find out the academic performance before and after receiving the discipline strategy. The researcher went through the academic results (in all subjects and obtained a mean score) of the identified student specifically in the exam which was done just before the discipline strategy was used on them. However, the results of the immediate exam which was done after the discipline strategy were used on them.

Data was analyzed with the help of the Statistical Package for Social Sciences (SPSS V20.0). The quantitative data was analyzed using paired sample t-test at .05 level of significance and repeated measures analysis of variance (ANOVA) to compare the academic performance of students before and after the discipline strategies had been given (Kothari, 2004).

\section{FINDINGS}

In this study, two hypotheses were tested;

HO1: There is no significant difference in academic performance of students by gender.

$\mathbf{H O}_{2}$ : There is no significant difference in academic performance of students by academic level.

\section{Academic Performance of Students by Gender Before and After Discipline Strategies}

In testing the first null hypothesis, a t-test for paired observations at .05 was computed in order to compare the means of girls and boys independently before and after discipline strategies were given. Table 1 show the results of the analysis for boys. 


\section{TABLE 1. ACADEMIC PERFORMANCE OF BOYS BEFORE AND AFTER THE DISCIPLINE STRATEGY}

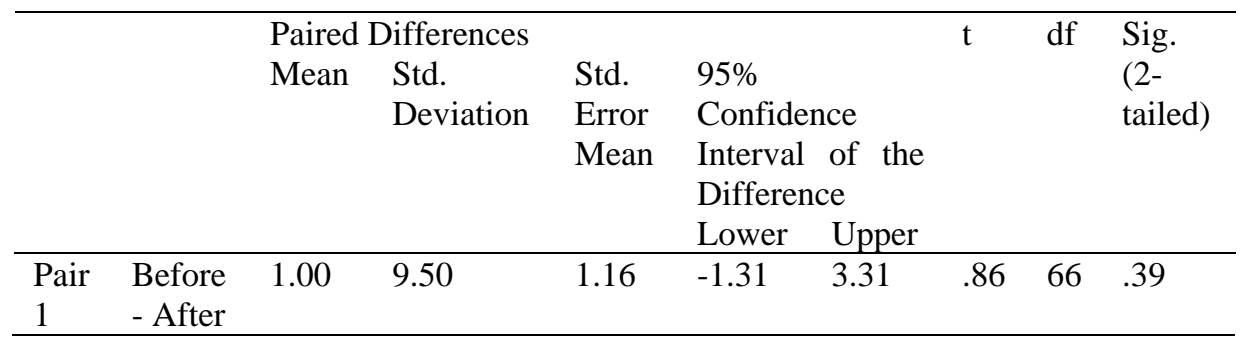

Source: Survey Data (2016)

Table 1 indicates that the computed t-value is .86 with a df of 66 . The critical t-value is 1.64 with a df of 66 . This is an indication that the critical value is higher than the $\mathrm{t}$-value $\left(\mathrm{t}_{\mathrm{ob}}=.86<\mathrm{t}_{\text {crit }}=1.64\right)$ which suggests that there is no significant difference in the academic performance of boys before and after they were given the discipline strategies. The academic performance of the boys did not show any major difference before and after the use of the discipline strategies.

\section{TABLE 2. ACADEMIC PERFORMANCE OF GIRLS BEFORE AND AFTER DISCIPLINE STRATEGIES}

\begin{tabular}{|c|c|c|c|c|c|c|c|c|}
\hline & \multicolumn{4}{|c|}{ Paired Differences } & \multirow{5}{*}{\multicolumn{2}{|c|}{ df }} & \multirow{5}{*}{$\begin{array}{l}\text { Sig. } \\
(2- \\
\text { tailed })\end{array}$} \\
\hline & & \multirow[t]{4}{*}{ Mean } & \multirow{4}{*}{$\begin{array}{l}\text { Std. } \\
\text { Deviation }\end{array}$} & \multirow{4}{*}{$\begin{array}{l}\text { Std. } \\
\text { Error } \\
\text { Mean }\end{array}$} & Confidence & & & \\
\hline & & & & & Interval of the & & & \\
\hline & & & & & Difference & & & \\
\hline & & & & & Lower Upper & & & \\
\hline $\begin{array}{l}\text { Pair } \\
1\end{array}$ & $\begin{array}{l}\text { Before } \\
\text { - After }\end{array}$ & 5.58 & 12.10 & 2.37 & 10.46 & 2.34 & 25 & .02 \\
\hline
\end{tabular}

Source: Survey Data (2016)

From the results in Table 2, the paired difference mean before and after the discipline strategies was 5.58 with a standard deviation score of 12.10 at $95 \%$ significance level. The computed t-value is 2.34 with a df of 25 . The critical t-value is 2.06 with a df of 25 . This implies that the t-value is more than the critical $\mathrm{t}$-value which can also be represented as $\left(\mathrm{t}_{\mathrm{ob}}=2.35>\mathrm{t}_{\text {crit }}=\right.$ 2.06). This suggests that there exist a significant difference in the academic performance of girls before and after the discipline strategies had been used on them. This implies that the academic performance of girls went down after they had received these discipline strategies. Also, this is an indication that the discipline strategies had a negative influence on the academic performance of girls in Rachuonyo North Sub County, Homabay County.

To test the first hypothesis $\left(\mathbf{H O}_{\mathbf{1}}\right)$ which state that there is no significant difference in academic performance of students by gender, the 
researcher used a paired sample t- test to compare the academic performance of boys and girls before and after the discipline strategies were used on them at .05 significance level. Therefore, the descriptive statistics are given in Table 3.

TABLE 3 ACADEMIC PERFORMANCE OF BOYS AND GIRLS BEFORE AND AFTER DISCIPLINE STRATEGIES

\begin{tabular}{llll}
\hline Gender & & Performance Before & Performance After \\
\hline \multirow{3}{*}{ Boys } & Mean & 36.71 & 35.71 \\
& N & 67 & 67 \\
& Std. Deviation & 17.37 & 15.78 \\
\hline \multirow{3}{*}{ Girls } & Mean & 35.73 & 30.15 \\
& N & 26 & 26 \\
& Std. Deviation & 19.12 & 13.26 \\
\hline \multirow{3}{*}{ Total } & Mean & 36.44 & 34.16 \\
& N & 93 & 93 \\
& Std. Deviation & 17.77 & 15.26 \\
\hline
\end{tabular}

Source: Survey Data (2016)

The results on Table 3 indicate that the mean average performance of boys declined slightly by 1.00 after the discipline strategies were used on them. In addition, the mean average performance of girls declined by 5.58. This implies that girls declined to a greater extent after the discipline strategies had been used on them than boys. To test whether these differences were significant, a paired sample t-test at .05 level of significance was computed and the results are given in Table 4.

\section{TABLE 4. ACADEMIC PERFORMANCE OF STUDENTS BY GENDER BEFORE AND AFTER DISCIPLINE STRATEGIES}

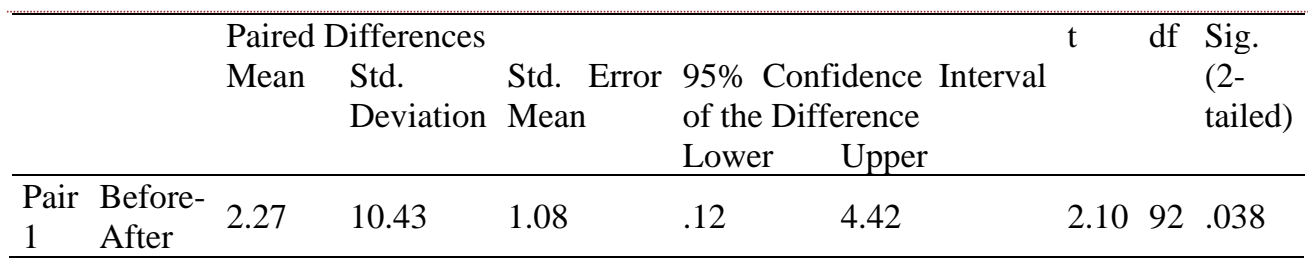

\section{Source: Survey Data (2016)}

From Table 4, the paired difference mean before and after the discipline strategies was 2.27 with a standard deviation score of 10.43 at .05 significance level. The computed t- value is 2.11 with a df of 92 . The critical $\mathrm{t}$-value is 1.96 with a df of 92 . This implies that the $\mathrm{t}$-value is more than the critical value which can also be represented as $\left(\mathrm{t}_{\mathrm{ob}}=2.11>\mathrm{t}_{\text {crit }}=1.96\right.$ at $\mathrm{p}<$ $.05)$. This suggests that there exist significant difference in the academic performance of girls and boys before and after the discipline strategies had been used on them. This implies that the hypothesis $\mathbf{H O}_{\mathbf{1}}$ which states there is 
no significant difference in academic performance of students by gender is rejected. These finding contradicts the finding of Kralevich, Slate, Kesley, Carmen, and Delgado (2010) who found that girls performed better than boys after these strategies had been used on them.

\section{Academic Performance of Students by Academic Level Before and After the Discipline Strategies}

In testing the second hypothesis $\left(\mathbf{H O}_{2}\right)$ which states that there is no significant difference in academic performance of students by academic level, the researcher computed a t-test for paired observation to compare the means of form two, form three, and finally form four students independently. Repeated measures analysis of variance (ANOVA) was thereafter computed to test the hypothesis. To begin with, a t-test for paired observation was computed to compare the academic performance of form two students before and after the discipline strategies and the results is shown in Table 5.

TABLE 5. ACADEMIC PERFORMANCE OF FORM TWO STUDENTS BEFORE AND AFTER DISCIPLINE STRATEGIES

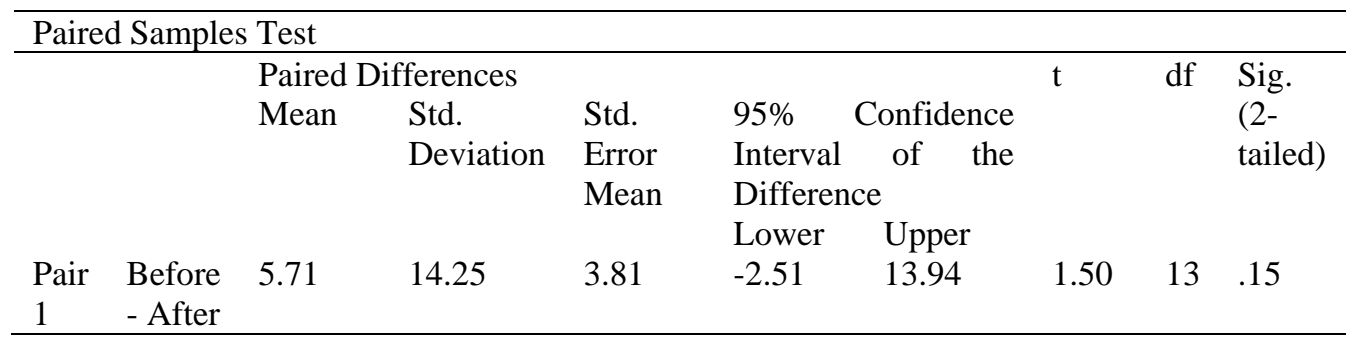

Source: Survey Data (2016)

The results in Table 5 indicate that the paired difference mean before and after the discipline strategies was 5.72 at $95 \%$ confidence level. The computed $\mathrm{t}$-value is 1.50 with a df of 13 . This is less than the critical t-value which is 2.16 with a df of 13 . This implies that the difference was not significant.

\section{TABLE 6. ACADEMIC PERFORMANCE OF FORM THREE STUDENTS BEFORE AND AFTER THE DISCIPLINE STRATEGIES}

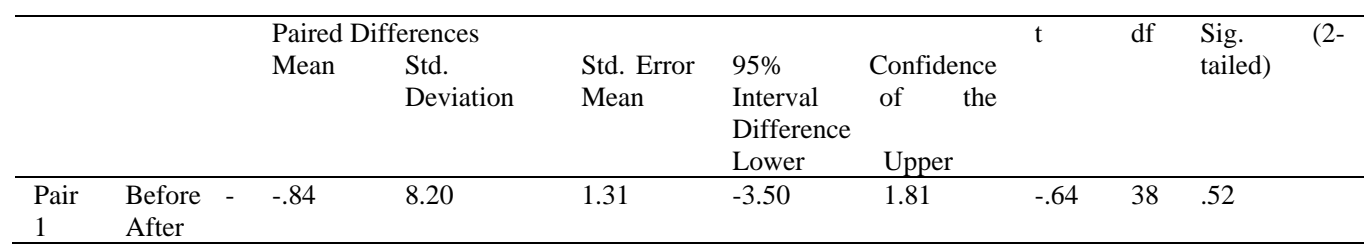

Source: Survey Data (2016) 
From Table 6 above, the paired difference mean before and after the discipline strategies was .84 with a standard deviation of 8.20 at .05 significance level. The computed t-value was .64 with a df of 38 . The critical $\mathrm{t}$-value is 1.96 with a df of 38 . This can also be represented as $\left(t_{o b}=0.64<t_{\text {crit }}\right.$ $=1.96$ ). This suggests that there is no significant difference in the academic performance of the form three students before and after the discipline strategies.

TABLE 7. ACADEMIC PERFORMANCE OF FORM FOUR STUDENTS BEFORE AND AFTER THE DISCIPLINE STRATEGIES

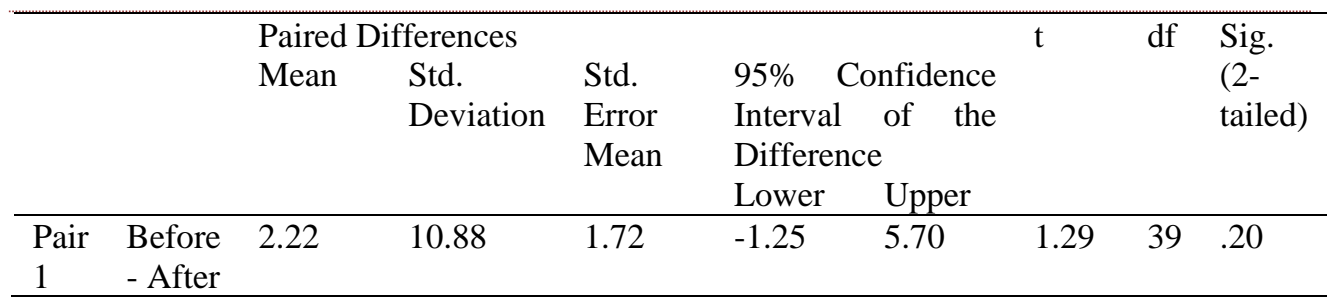

Source: Survey Data (2016)

Table 7 indicates that the paired difference mean before and after the discipline strategies was 2.22 with a standard deviation of 10.88 at $5 \%$ level of significance. The computed t-value is 1.29 with a df of 39 . The table value is 1.96 with a df of 39 . This implies that the t-value is less than the critical tvalue. From these results, there is an indication that there is no significant difference in the academic performance of the form four students.

To test the second hypothesis $\left(\mathbf{H O}_{2}\right)$ which states that there is no significant difference in academic performance of students by academic level, the researcher used repeated measure Analysis of Variance (ANOVA) to compare the academic performance of the form 2, 3, and 4 students at .05 level of significance.

\section{TABLE 8. REPEATED MEASURES ANOVA}

\begin{tabular}{llllll}
\hline & Sum of Squares & df & Mean Square & F & Sig. \\
Between Groups & 231786.86 & 1 & 231786.86 & 468.64 & .000 \\
Within Groups & 99.44 & 92 & 56.01 & & \\
Total & 231886.30 & 93 & & & \\
\hline
\end{tabular}

Source: Survey Data (2016)

From the repeated measures ANOVA, $F(1,92)=468.64 \geq p=.000$. However, this means the null hypothesis $\mathrm{HO}_{2}$ which states that there is no significant difference in academic performance of students by academic level 
is rejected. Thus, there is a significant difference in academic performance of the students by academic level.

\section{DISCUSSIONS}

The study aimed at examining the influence of the discipline strategies on academic performance based on gender and the academic level of the student. The results revealed that the academic performance of girls went down after they had received the discipline strategies with a mean difference of 5.58 and a $\mathrm{t}$ - value of 2.35 which was greater than the critical t- value of 2.06. This is an indication that the discipline strategies had a negative influence on the academic performance of girls in Rachuonyo North Sub County. This finding is in agreement with the findings of Perry (2015) and Dahir (2010) which revealed that suspension is harmful to the student's academic performance. On the other hand, the study revealed that the academic performance of boys went down slightly with a mean difference of 1.00 which was not statistically significant. This was an indication that the discipline strategies had a negative influence on girls' academic performance more than it had on boys' academic performance. This is contrary to the study findings of Kralevich, Slate, Kelsey, Carmen, and Delgado (2010) which confirmed that girls who received suspension for example were performing well than boys who received the same discipline strategy. In regard to the first hypothesis which stated that there is no significant difference in academic performance of students by gender, the results confirmed that there was a significant difference in academic performance of students by gender since the $\mathrm{t}$ - value was greater than the critical t- value.

In response to the second objective, the study revealed that the academic performance of the form two students declined after the discipline strategies had been used on them with a mean difference of 5.71. On the other hand, the form three academic performances increased slightly after the discipline strategies had been used on them with a mean difference of 0.84 . Nevertheless, this difference was not statistically significant. The studies also revealed that the academic performance of the form four students declined slightly with a mean difference of 2.22 at a t-value of 1.29 which was less than the critical t- value of 1.960 and therefore this difference was not statistically significant.

In testing the second null hypothesis which stated that there is no significant difference in academic performance of students by academic level, the alternative hypothesis was accepted with $F(1,92)=468.64 \geq p=.000$. This means that there was a significant difference in academic performance of the form two, three, and four students before and after the discipline strategies had been used on them in Rachuonyo North Sub County, Homabay County. 
The study findings therefore revealed that there was significant difference in academic performance depending on the academic level of the student.

\section{CONCLUSION AND RECOMMENDATIONS}

From the study findings and discussions, the following conclusions were deduced. Girls' academic performance is adversely influenced by these discipline strategies than the academic performance of boys since their academic performance goes down largely after the discipline strategies have been used on them.

The discipline strategies influence the academic performance of students in different ways depending on the academic level of the student. Consequently, the form two students' academic performance decline drastically, the form three academic performance improve, and the form four academic performance decline slightly. The study recommends that education stakeholders should find alternative to exclusionary discipline, especially for girls. This is because girls are adversely affected by the discipline strategies that require that they go home for a certain period of time. More research should be done on the best discipline strategies at each academic level since the strategies that involve removing a student from academic setting are seen to influence their academic performance in different ways. Therefore, this would ensure that discipline is maintained in a school and at the same time, the academic performance of students at different academic levels is not interfered with.

\section{References:}

Dahir, A. (2010). An Analysis of Predictors of Exclusionary Discipline Practices and their Relationship with Student Achievement Using Hierarchical Linear Modeling. PhD Dissertation, Lousiana State University

Kothari, C. R. (2004). Research methodology: Methods and Techniques, (2nd ed), New Delhi: New Age International Publishers.

Kothari, C. R., \& Gaurav, G. (2014). Research Methodology: Methods and Techniques, (2nd ed), New Delhi: New Age International Publishers.

Kralevich, M., Slate, J. R., Tejeda-Delgado, C., \& Kelsey, C. (2010) Disciplinary Methods and Student Achievement: A Statewide Study of Middle School Students. Connexions module.

Mugenda, O. \& Mugenda, A. (1999). Research Methods: Qualitative and Quantitative Approaches. Nairobi: Acts Press.

Nyagaka, E. \& Odongo, A. (2013). Leadership Styles of Head teachers and their Impact on Student Academic Performance in Secondary Schools, Nyamaiya Division, Nyamira District, Kenya. Journal of Educational and Social Research, 3(3),157-172. 
Ogweno, P. Kathuri, N. \& Obara, J. (2014). Influence of Students Characteristics on Academic Performance in Secondary Agriculture in Rachuonyo North Sub County, Kenya. Internatonal Journal of Education and Research, 2(2), 1-12

Perry, B.L (2015). The Overuse of Suspension in American Public Schools Threatens the Success of all the Students. Blogs.Ise.ac.uk

Thornberg, R. (2008). School Children's Reasoning about School Rules. Research papers in Education 23 (1) 37-52.. 